\section{Timing the Establishment of Kentucky Bluegrass : Perennial Ryegrass Mixtures for Football Fields}

\author{
John C. Stier ${ }^{1}$, Eric J. Koeritz, and Mark Garrison \\ Department of Horticulture, University of Wisconsin, 1575 Linden Drive, \\ Madison, WI 53706-1590
}

Additional index words. seed, traffic, Poa annua, annual bluegrass, competition, germination, weeds, sports turf

\begin{abstract}
Sports field construction contracts in cool-season areas often stipulate a 9- to 12-month period between seeding and opening for play. Seed mixtures are usually dominated by slow-establishing Kentucky bluegrass (KBG; Poa pratensis L.) and contain lower proportions of perennial ryegrass (PRG; Lolium perenne $\mathrm{L}$.) for quick cover. Our objective was to evaluate the effect of planting time on three KBG : PRG mixes, a $100 \%$ PRG blend, and their ability to sustain football-type traffic. Field plots were seeded in late summer, as a dormant planting in late fall, and in the following spring. Plots received simulated football traffic, split for one or four weekly games, from mid-August through mid-November of the year in which spring seeding occurred. The experimental design was a strip-split-plot, randomized block with four replications. The study was repeated a second year. All seeding dates provided acceptable turf quality regardless of seed type by September. However, summer seedings of KBG-based mixtures provided better turf quality than mixtures planted in the spring, whereas dormant-seeded mixtures provided the poorest turf quality. Turf seeded with $100 \%$ PRG was less sensitive to seeding date, with summer or spring seedings providing similar quality and dormant seedings superior to KBG-based dormant seedings. Summer seedings also resulted in the least amount of broadleaf weeds the next year with dormant seedings having the most weeds, particularly with plots seeded to $95 \%$ KBG. All KBG-based seed mixtures provided turf containing $\approx 50 \%$ KBG or more by September, although the amount of KBG remaining after traffic was significantly greatest in plots seeded to $95 \%$ KBG and least in plots seeded with $70 \%$ KBG. Pure PRG swards provided acceptable turf quality throughout the traffic period but should be used cautiously as a result of winterkill potential and crown rust disease (Puccinia coronata Corda f. sp. agropyri Erikss.). Different amounts of traffic did not affect turf species proportions. The most consistently desirable results may be obtained with a mixture containing $70 \%$ to $80 \%$ KBG and $30 \%$ to $20 \%$ PRG, respectively. Mixtures dominated by KBG should be seeded in late summer for best results.
\end{abstract}

Sports fields are often constructed under short time lines. In the U.S. school system, football seasons last from mid-August to mid-November. Many consultants and contractors like to have 9 to 12 months between seeding a $\mathrm{C}_{3}$ turfgrass-based field and when play begins to ensure sufficient turf development. In most cases, this timeline is not feasible nor is documentation available to show such a timeline is needed. Furthermore, the timeline needed for turf development from seeding before it can withstand sports traffic may vary with the grass species or mixes used, because perennial ryegrass

\footnotetext{
Received for publication 24 May 2007. Accepted for publication 31 Aug. 2007.

We thank L.L. Olds Seed Company for supplying the seed and Spring Valley Turf Products for supplying the fertilizer used in this project.

Mention of a trademark, proprietary product, or vendor does not constitute an endorsement compared to similar products or suppliers.

${ }^{1}$ To whom reprint requests should be addressed; e-mail jstier@wisc.edu
}

(PRG) establishes dramatically faster than Kentucky bluegrass (KBG).

An equivalent amount of $\mathrm{KBG}$ and $\mathrm{PRG}$ is often desired in a sward with the intent to prevent significant damage whenever one species is susceptible to a particular biotic or abiotic stress. Previous research has indicated that anywhere from $50 \%$ to $95 \% \mathrm{KBG}$ seed by weight was needed to obtain a 50:50 sward mixture with PRG as a result of slow germination of KBG (Brede and Duich, 1984a, 1984b; Larsen et al., 2004; Larsen and Bibby, 2005; Stier et al., 2005). In some cases, a $100 \%$ PRG seed mix may be necessary and practical depending on the time of year sown. To maximize growth and avoid either winterkill or high temperature (summer) stress of immature plants, recommendations are to plant $\mathrm{C}_{3}$ turfgrasses in late summer, although dormant (late fall) or spring seedings are often used out of necessity or convenience (Stier, 2000). Our primary objective was to determine the relative effectiveness of summer, dormant, and spring seeding dates for $\mathrm{KBG}$-based mixtures or PRG and their tolerance to autumn traffic.
Our secondary objective was to determine how the seed mixtures affected turf composition when subjected to traffic.

\section{Materials and Methods}

Field studies were conducted twice over 2 successive years in Madison, WI, to evaluate the effects of four seed types planted at three different times and subjected to two different levels of traffic. The soil type was a Batavia silt loam (fine-silty, mixed, superactive, mesic, Fluvaquentic Endoaquoll) with $\mathrm{pH}$ 7.4 , phosphorus at $85 \mathrm{mg} \cdot \mathrm{kg}^{-1}$, potassium at $160 \mathrm{mg} \cdot \mathrm{kg}^{-1}$, and $3.9 \%$ organic matter. The experimental design was a strip-split-plot, randomized block with four replications. Traffic was applied as a strip-plot treatment to mature turf from mid-August to midNovember. A Brinkman Traffic Simulator (1.2-m width) was used to simulate either one or four football games weekly for a total of either 14 or 56 games annually (Cockerham and Brinkman, 1989). Nontrafficked plots were not included because all football fields are intended to receive some level of play. Main plots $(3.6 \mathrm{~m} \times 10.9 \mathrm{~m})$ were planting dates: late summer (30 Aug. 2004 and 1 Sept. 2005), a dormant seeding in late autumn (26 Nov. 2004 and 29 Nov. 2005), and early spring (28 Apr. 2005 and 27 Apr. 2006).

Seed types were subplots $(1.4 \times 3.6 \mathrm{~m})$ and included a $100 \%$ PRG blend and mixtures of 95:5 KBG : PRG (w/w), 80:20, and 70:30. The seed blend and mixtures were prepared and donated by L.L. Olds Seed Co. (Madison, WI) by a certified seed technologist. Seed mixtures were based on information from a previous study and represent the range of mixtures commonly used for athletic fields in the upper Midwest (Stier et al., 2005). KBG cultivars used in the mixtures were 'Touchdown', 'Odyssey', and 'Fairfax', whereas the PRG cultivars were 'Manhattan 4', 'SR4500', and 'Fiesta 3'. Cultivars within a species were blended in equal proportions. We seeded plots at rates needed to achieve two pure live seeds (PLS) per square centimeter. Seeding rates were determined by multiplying the germination percent by seed purity percent to determine PLS, then calculating the density of each seed species in a mixture using a 1000-seed sample, and adjusting the seed weight accordingly for the seeding of each treatment. Seeding rates were as follows: $9.8 \mathrm{~g} \cdot \mathrm{m}^{-2}$ for 95:5 mixture, $11.4 \mathrm{~g} \cdot \mathrm{m}^{-2}$ for $80: 20,12.2 \mathrm{~g} \cdot \mathrm{m}^{-2}$ for $70: 30$, and $38.4 \mathrm{~g} \cdot \mathrm{m}^{-2}$ for $100 \% \mathrm{PRG}$.

Starter fertilizer $(13 \mathrm{~N}-11.4 \mathrm{P}-10 \mathrm{~K})$ was applied at time of seeding to provide phosphorus at $2.2 \mathrm{~g} \cdot \mathrm{m}^{-2}$. Biodegradable Futerra covers (Profile Products LLC, Buffalo Grove, IL) were placed over new seedings to enhance germination and prevent erosion. Irrigation was supplied after seeding of summer and spring-planted plots daily until 2 to 3 weeks after germination occurred. Dormant-seeded plots received irrigation at the same time as spring-seeded plots. For summer-seeded plots, irrigation continued once weekly for an 
additional 4 weeks before allowing turf to harden off for winter. The next year, all plots were irrigated once weekly until the third week in October. Irrigation was supplied during the growing season to replenish $100 \%$ of the weekly estimated evapotranspiration as determined using a weather station (Campbell Scientific, Logan, UT) and a modified Penman equation.

Mowing began when irrigation was reduced to once weekly $(\approx 3$ weeks after germination). Turf was mowed at $3.8-\mathrm{cm}$ height one to three times weekly during the growing season, depending on the growth rate, using a reel mower with clippings returned. We applied a broadleaf herbicide containing 2,4-D (2,4-dichlorophenoxyacetic acid, 30.6\%), MCPP (2-methyl 1-4 chlorophenoxy propionic acid, $8.2 \%$ ), and triclopyr (3,6-dichloro-o-anisic acid, 2.8\%) on 21 June 2005 and 29 June 2006 to control broadleaf weeds. Plots were fertilized with nitrogen at $4.9 \mathrm{~g} \cdot \mathrm{m}^{-2}$ using a $25 \mathrm{~N}-0.9 \mathrm{P}-3.3 \mathrm{~K}$ fertilizer each time in early Oct. 2004/2005, late May $2005 / 2006$, early Sept. 2005/2006, and early Oct. 2005/2006.

We rated turf quality monthly during the growing season on a 1 to 9 scale with $1=$ bare soil/dead turf, $9=$ ideal turf, and $6=$ acceptable turf. Ground cover and composition were quantified using an optical point quadrat in Aug. and Oct. 2005 and monthly from August through November in 2006 (Nov. 2005 data collection was thwarted by snow cover). The quadrat measured $0.6 \mathrm{~m} \times 1.2 \mathrm{~m}$ with $5 \times 10-\mathrm{cm}$ grids. Data were collected by determining the lack or type of plant (i.e., broadleaf weed or grass), and if a grass then tiller type (e.g., KBG, PRG, or Poa annua L.), directly underneath 100 intersections of the grid.

Analysis of variance was used to identify the effects of year, traffic, time of seeding, seed mixture, and potential interactions. Data collected before the start of traffic were analyzed with timing as a main plan and mixture as a subplot. After traffic was started, traffic and time of seeding were evaluated as horizontal and vertical factors, respectively, whereas seed mixture was treated as a subplot (Statistix, 2003). Significant year main effects or interactions consistently existed for all parameters measured so data were reanalyzed and displayed separately for each year. Fisher's least significant difference (LSD) values were used to separate treatment means when $P$ values were $\leq 0.05$.

\section{Results and Discussion}

Treatment effects on turf quality before traffic. Pretraffic turf quality was consistently affected by seed mix but with different results in each year (Fig. 1). In 2006, turf quality during July through August was two to four units (1-9 scale) below 2005 ratings. Air and soil temperatures during this time were similar between years (Fig. 2), whereas $50 \%$ more precipitation occurred during June through August in $2006(31.6 \mathrm{~cm})$ than
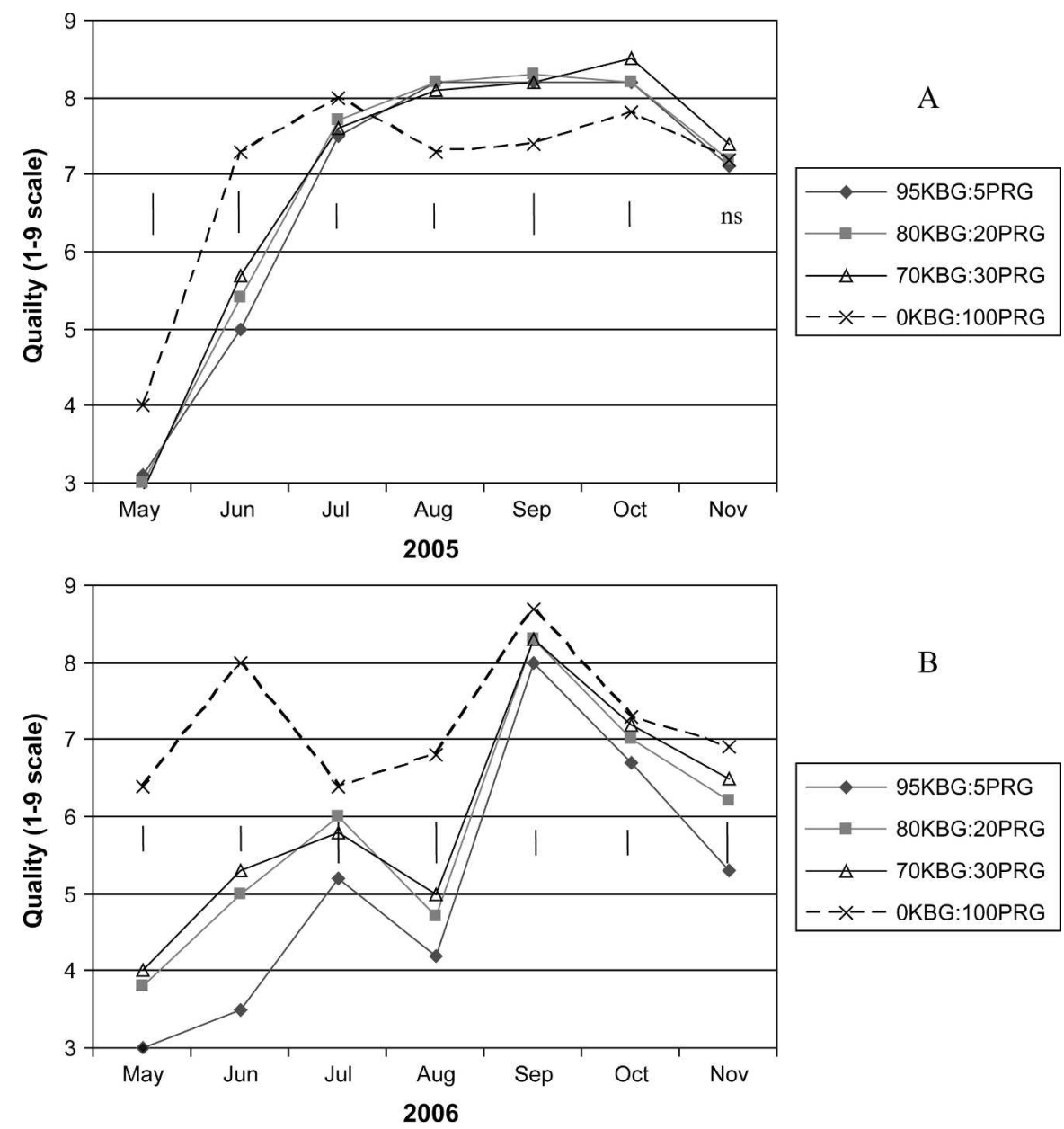

Fig. 1. Seed mixture effects on turf quality before and during simulated football traffic applied from midAugust to mid-November. Ratings were collected during midmonth of both years. 95:5 $=95 \%$ Kentucky bluegrass (KBG; Poa pratensis) : 5\% perennial ryegrass (PRG;Lolium perenne) seed mix by weight; $80: 20=80 \% \mathrm{KBG}: 20 \% \mathrm{PRG} ; 70: 30=70 \% \mathrm{KBG}: 30 \%$ PRG; $0: 100=100 \%$ PRG. Vertical lines indicate least significant difference $e_{0.05}$ values for comparing mixture effects at a given rating date.

$2005(20.4 \mathrm{~cm})$. Greater P. annua populations during Summer 2006 reduced the turf quality as a result of prolific seedhead production followed by senescence (Table 1 ). Crown rust disease occurred in July 2006 and was particularly severe on plots seeded to $100 \%$ PRG but minor on KBG mixes as a result of the low amount (less than $30 \%$ ) of PRG. On a scale of 1 to 9, with 1 equal to $100 \%$ diseased turf and 9 equal to no disease, plots seeded to $100 \%$ PRG rated 4.6, whereas mixtures containing $30 \%, 20 \%$, and $5 \% \mathrm{PRG}$, respectively, rated $7.3,7.5$, and 8.1 with an $\mathrm{LSD}_{0.05}$ value of 0.4 . Despite the relatively poor turf quality of KBG : PRG mixtures when traffic started in mid-August of 2006, quality improved dramatically to well above acceptable levels by mid-September before declining due to traffic (Fig. 1).

Planting times regularly affected the ability of a particular seed mix to provide a given level of turf quality, particularly before traffic treatments occurred. Dormant seedings had the worst turf quality of any seeding date until late summer, although PRG was much less affected than KBG-dominated mixtures (Table 2). Likewise, spring seedings of
$100 \%$ PRG provided high-quality turf by June of each year, whereas KBG-dominated mixtures took 1 (2005) to 3 (2006) more months to provide acceptable-quality turf (6.0 or greater rating). Late summer seedings usually provided the best turf quality throughout the next growing season and were least affected by seed mix. PRG suffered partial winterkill, particularly in the lowlying fourth replication, during the winter of 2004 through 2005, but growth from surviving turf provided comparable quality to KBG : PRG mixtures by June 2005.

Broadleaf weed cover was affected by the planting time for a given seed type. Dormant seedings resulted in approximately two to four times more weeds compared with either summer or spring seedings with $100 \%$ PRG swards having the fewest weeds (Table 3). Otherwise, seed mixture had little effect on broadleaf weeds. Broadleaf weed cover was negligible in mid-May, covering less than $2 \%$ of the ground in summer seedings, less than $3 \%$ in spring seedings, and less than $10 \%$ or $17 \%$ in the dormant-seeded plots in 2005 and 2006, respectively (data not shown). By June, broadleaf weed populations ranged between 

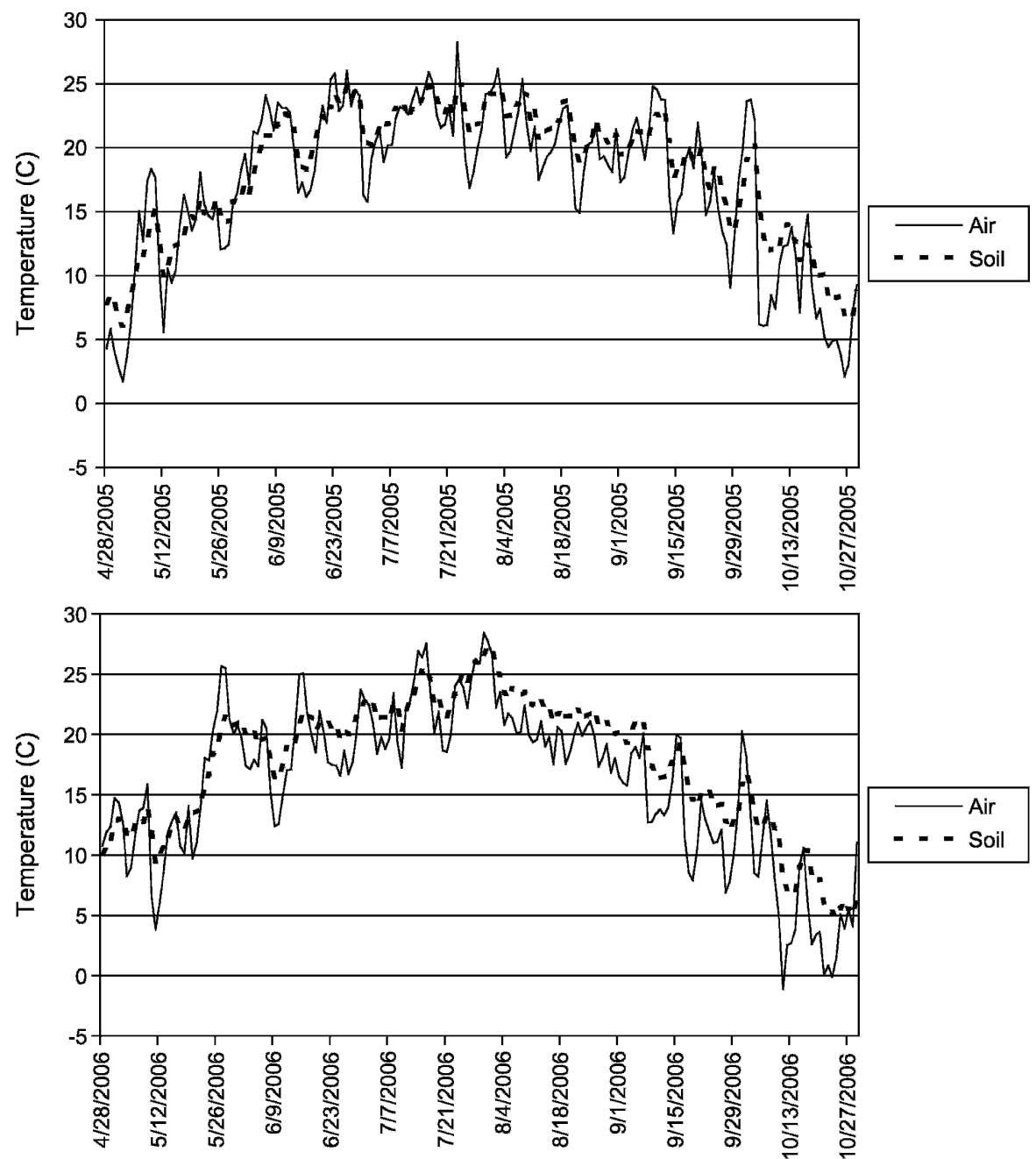

Fig. 2. Mean air and soil ( $5 \mathrm{~cm}$ depth) temperatures at the O.J. Noer Turfgrass Research and Educational Facility, Verona, WI, in (A) 2005 and (B) 2006.

$7.5 \%$ and $14.9 \%$ groundcover in 2005 and $5.5 \%$ to $26.9 \%$ in 2006 . The main weeds were dandelion (Taraxacum officinale), black medic (Medicago lupulina), lambsquarters (Chenopodium album), smartweed (Polygonum pensylvanicum), and yellow woodsorrel (Oxalis stricta). Weeds were virtually eliminated within 4 weeks of herbicide application with the exception of some $O$. stricta, which is notoriously resistant to phenoxy herbicides (Marshall, 1987). The weeds did not seem to have any long-lasting impact on turf quality once they were removed.

Treatment effects on turf quality during traffic periods. Traffic generally affected all turf treatments similarly regardless of seed mixture or seeding date, because the effect of traffic intensity was affected by seed mix and timing on only one date each in 2005 (data not shown). Four weekly simulated games decreased turf quality in October and November of 2005 and September, October, and November of 2006 compared with one weekly game $(P \leq 0.05)$. In 2005 , turf quality decreased from 8.1 rating in September to 7.6 in October and 6.4 in November when subjected to four weekly simulated football games, whereas quality for each respective
Seed mix had little effect on the amount of exposed soil during the traffic period. By Oct. 2005 , the $100 \%$ PRG treatment had significantly more exposed soil than any mixture, but over $95 \%$ of the ground was still covered by vegetation so practical differences were negligible (Table 1). In 2006, there was no consistent effect of seed mixture on the amount of exposed soil, although the amount of exposed soil increased during the traffic period to between $\approx 12 \%$ and $17 \%$ by midNovember. The amount of exposed soil in 2006 was greater than in 2005 as a result of freezing air temperatures beginning early October, which effectively stopped turf recovery although soil temperatures at a 5 -cm depth remained at $\approx 5$ to $8{ }^{\circ} \mathrm{C}$ (Fig. 2).

Seed mixture and planting time effects on sward composition during traffic periods. All three mixtures provided at least $50 \% \mathrm{KBG}$ in the plant population, whereas PRG constituted no more than $30 \%$ of the sward from any mixture (Table 1). The $80: 20$ and $70: 30$ mixtures produced similar amounts of $\mathrm{KBG}$ and PRG plants, whereas the $95: 5 \mathrm{mix}$ had more KBG and less PRG than the other two mixtures (Table 1). P. annua comprised between $\approx 10 \%$ and $25 \%$ of the groundcover and was least in $100 \%$ PRG-seeded plots. A time of seeding by seed type interaction affected KBG percentage in the swards in 2005 but not 2006. In 2005, increased amounts of PRG in seed mixes decreased the amount of KBG in the sward when seeded in spring more than when seeded in late summer or as a dormant seeding in late fall (Table 4). When seeded in spring 2005, only mixtures containing 95\% KBG seed (by volume) provided at least $50 \% \mathrm{KBG}$ in the sward, whereas mixtures containing $70 \%$ and $80 \%$ KBG seed were dominated by PRG. The relatively large differences in the amount of KBG resulting from spring plantings were likely the result of spring weather conditions. Air and soil temperatures were $\approx 5^{\circ} \mathrm{C}$ greater in 2006 compared with 2005 (Fig. 1.), which presumably initiated more rapid establishment of PRG. Although KBG has a lower base temperature requirement $\left(2.6{ }^{\circ} \mathrm{C}\right)$ than PRG $\left(3.6^{\circ} \mathrm{C}\right), \mathrm{KBG}$ has almost double the germination time (Larsen and Bibby, 2005). Precipitation data were similar between years, averaging $7.7 \mathrm{~cm}$ in May of both 2005 and 2006.

Brede and Duich (1984b) reported that an 80 : $20 \mathrm{KBG}$ : PRG seed weight ratio provided a sward with equivalent KBG and PRG shoots. Our data suggest variability exists, sometimes as a function of seeding time. Our sward composition data were similar to data from mixtures containing elite KBG cultivars published in Stier et al. (2005), although one of the current KBG cultivars ('Odyssey') and all three of the PRG cultivars were different between the two projects. Several comparison trials containing one of the PRG cultivars ('Manhattan 3') in Stier et al. (2005) and the three used in the current study indicated all four had similar spring greenup, seedling establishment, winterkill, and autumn density (NTEP, 2003). Poa annua was a major 
Table 1. Seed mixture effects on percent groundcovered by grasses and subjected to simulated football traffic from mid-August to mid-November, Madison, WI.

\begin{tabular}{|c|c|c|c|c|c|c|}
\hline \multirow[b]{2}{*}{ Seed mixture ${ }^{z}$} & \multicolumn{2}{|c|}{2005} & \multicolumn{4}{|c|}{2006} \\
\hline & 18 Aug. & 20 Oct. & 17 Aug. & 22 Sept. & 26 Oct. & 20 Nov. \\
\hline & \multicolumn{6}{|c|}{ Kentucky bluegrass (\%) } \\
\hline $95: 5$ & 70.4 & 67.7 & 48.7 & 65.0 & 63.0 & 53.9 \\
\hline $80: 20$ & 59.7 & 56.1 & 49.1 & 53.1 & 55.1 & 41.7 \\
\hline $70: 30$ & 58.0 & 54.0 & 48.1 & 45.5 & 47.8 & 38.8 \\
\hline $0: 100$ & 0.2 & 0.2 & 2.9 & 10.5 & 2.9 & 0.0 \\
\hline \multirow[t]{2}{*}{$\mathrm{LSD}_{0.05}$} & 6.7 & 6.2 & 8.8 & 12.8 & 8.6 & 5.7 \\
\hline & \multicolumn{6}{|c|}{ Perennial ryegrass $(\%)$} \\
\hline $95: 5$ & 13.5 & 9.6 & 11.3 & 16.9 & 12.0 & 14.0 \\
\hline $80: 20$ & 24.5 & 16.5 & 17.5 & 17.2 & 21.7 & 26.9 \\
\hline $70: 30$ & 30.4 & 20.8 & 20.9 & 15.2 & 25.9 & 28.8 \\
\hline $0: 100$ & 85.0 & 76.5 & 77.0 & 66.4 & 74.3 & 72.0 \\
\hline \multirow[t]{2}{*}{$\operatorname{LSD}_{0.05}$} & 7.8 & 4.8 & 7.4 & 15.3 & 8.2 & 4.0 \\
\hline & \multicolumn{6}{|c|}{ Poa annua $(\%)$} \\
\hline $95: 5$ & 16.0 & 21.5 & 24.9 & 17.5 & 17.2 & 17.5 \\
\hline $80: 20$ & 15.6 & 25.1 & 21.3 & 19.3 & 16.0 & 17.6 \\
\hline $70: 30$ & 11.2 & 23.6 & 20.8 & 23.0 & 19.0 & 19.9 \\
\hline $0: 100$ & 9.6 & 18.7 & 12.2 & 10.7 & 13.0 & 10.8 \\
\hline \multirow[t]{2}{*}{$\operatorname{LSD}_{0.05}$} & 4.8 & NS & 7.4 & 6.7 & 4.3 & 4.4 \\
\hline & \multicolumn{6}{|c|}{ Exposed soil (\%) } \\
\hline $95: 5$ & 0.0 & 0.9 & $15.8^{y}$ & 2.0 & 7.7 & 17.2 \\
\hline $80: 20$ & 0.0 & 1.4 & 12.5 & 2.7 & 7.0 & 13.8 \\
\hline $70: 30$ & 0.0 & 0.8 & 11.6 & 2.2 & 6.4 & 12.6 \\
\hline $0: 100$ & 1.8 & 4.3 & 7.8 & 4.0 & 9.9 & 17.2 \\
\hline $\mathrm{LSD}_{0.05}$ & 0.6 & 1.4 & 4.6 & 1.8 & 2.5 & 3.5 \\
\hline
\end{tabular}

${ }^{\mathrm{z}}$ Mixtures were ratios (by weight) of Kentucky bluegrass (Poa pratensis) : perennial ryegrass (Lolium perenne).

${ }^{y}$ Data from this month included broadleaf weed counts.

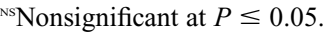

$\mathrm{LSD}=$ least significant difference.

Table 2. Turf quality affected by proportions of Kentucky bluegrass and perennial ryegrass as a function of planting time in Wisconsin.

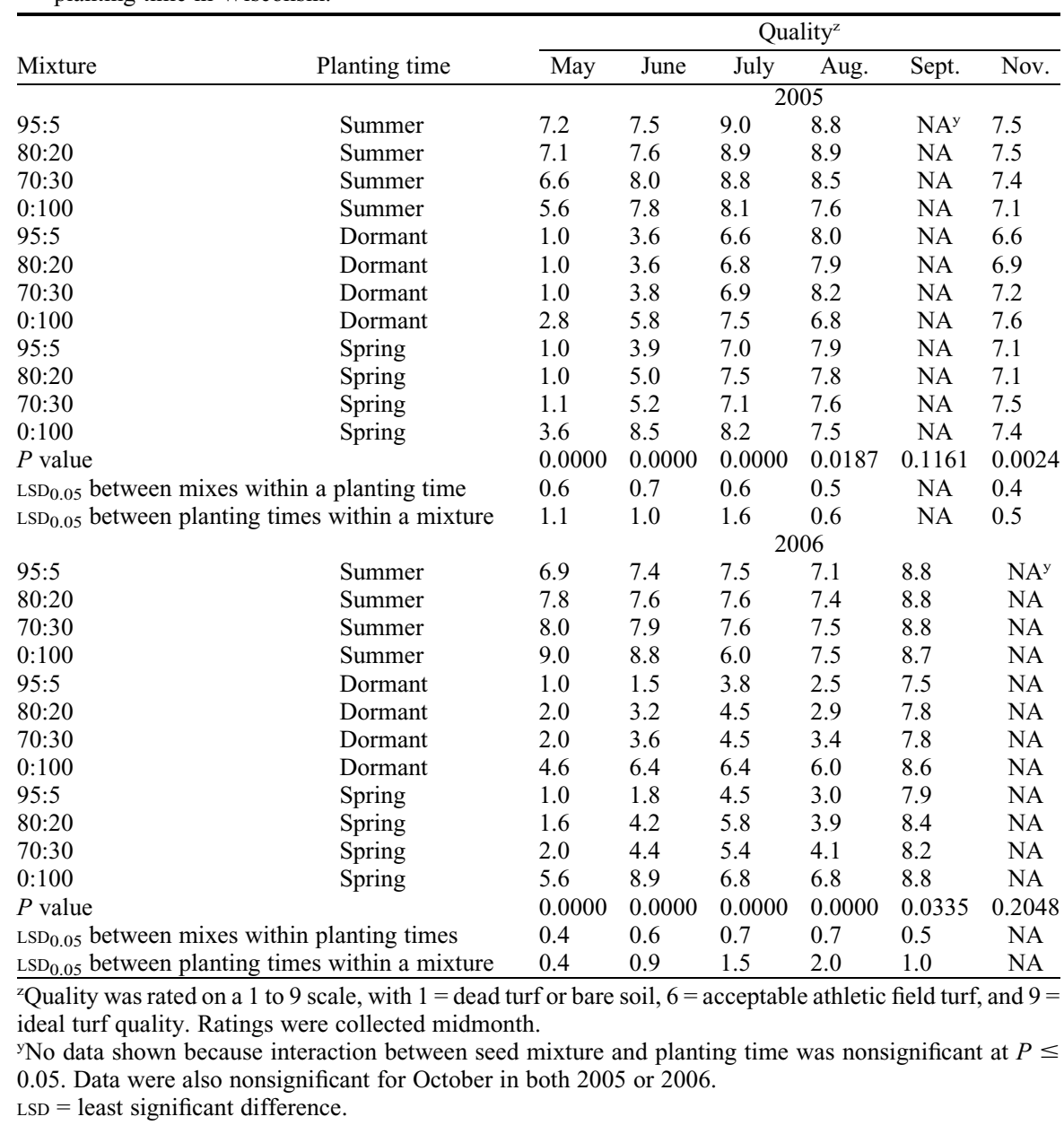

component of the swards in the current study ( $10 \%$ to $25 \%$ of the groundcover) but not in Stier et al. (2005), probably as a result of the greater age of the turf area used in the current study. Poa annua amounts were similar among all three mixtures but were least in plots seeded to $100 \%$ PRG (Table 1), indicating PRG alone was better able to outcompete the $P$. annua than a PRG mixture dominated by KBG. The actual impact of P. annua on competition between KBG and PRG appeared to be negligible because the proportions of KBG and PRG in swards of the current study were similar to those reported in Stier et al. (2005). Studies designed to measure the impact of $P$. annua on establishment of KBG and PRG mixtures might be helpful in determining the ecological dynamics of the three species.

In our study, the amount of traffic did not affect the relative proportions of grass species (data not shown). Swards with little or no traffic have been dominated by PRG several years after establishment when the seed mix contained as little as $10 \%$ PRG by weight (Dunn et al., 2002; Hsiang et al., 1997). In addition, traffic forces might appear to further shift a sward's composition toward PRG because Shearman and Beard (1975a) reported PRG had better traffic tolerance than KBG Minner and Valverde (2005), however, showed newer varieties of KBG and PRG had similar reactions to low and high traffic. Consequently, the proportion of a KBG : PRG mixture may not be critical for maintaining a given percent groundcover. In the short term, our study could not confirm nor refute the potential dominance of PRG because populations appeared to decline between Aug. and Oct. 2005 while remaining steady or increasing between Aug. and Nov. 2006 (Table 1). A long-term (greater than 3 years) analysis of the effects of regular traffic on species proportions of KBG : PRG mixtures would be useful. Information is also needed to determine if breeding PRG for improved turf quality has diminished the characteristics such as lignocellulose content, which correlated with superior traffic tolerance (Shearman and Beard, 1975b). Most importantly, information is needed on long-term recovery and sustainability of KBG:PRG mixtures subjected to annual traffic without overseeding.

\section{Conclusions}

KBG-based seed mixtures provide more consistent results for sports turf than $100 \%$ PRG but should be seeded the year (summer) before use to ensure acceptable turf quality at the beginning of the football playing season. KBG mixtures containing $70 \%$ to $80 \% \mathrm{KBG}$ seed by weight will sometimes have better traffic tolerance than areas seeded to mixtures containing 95\% KBG by weight. Different levels of traffic did not affect turf species composition, and high-quality athletic turf does not necessarily depend on having equivalent proportions of KBG and PRG in the sward. 
Table 3. Interaction of seed mixture and planting season on broadleaf weed populations in Kentucky bluegrass and perennial ryegrass turf, Madison, WI.

\begin{tabular}{|c|c|c|c|c|c|c|}
\hline \multirow[b]{4}{*}{ Ratio $^{\mathrm{y}}$} & \multicolumn{3}{|c|}{20 June 2005} & \multicolumn{3}{|c|}{16 June 2006} \\
\hline & \multicolumn{6}{|c|}{ Time of seeding $\bar{z}$} \\
\hline & Summer & Dormant & Spring & Summer & Dormant & $\overline{\text { Spring }}$ \\
\hline & \multicolumn{6}{|c|}{ Percent ground area covered by weeds } \\
\hline$\overline{95: 5}$ & 1.4 & 41.2 & 14.9 & 1.5 & 26.9 & 6.1 \\
\hline $80: 20$ & 0.9 & 31.9 & 8.0 & 2.1 & 17.5 & 4.4 \\
\hline $70: 30$ & 1.4 & 31.9 & 7.5 & 1.1 & 14.9 & 6.0 \\
\hline $0: 100$ & 1.5 & 11.1 & 7.5 & 0.4 & 5.5 & 1.5 \\
\hline $\mathrm{LSD}_{0.05}$ & & 5.5 & & & 3.1 & \\
\hline $\operatorname{LSD}_{0.05}$ & g times & 7.8 & & & 4.4 & \\
\hline
\end{tabular}

${ }^{2}$ Summer $=30$ Aug./1 Sept.; dormant $=$ late November, spring = late April.

${ }^{\mathrm{y}}$ Ratio shown reflects the seed mixture percentages (by weight) of Kentucky bluegrass and perennial ryegrass.

LSD $=$ least significant difference.

Table 4. Seed mixtures have different effects on percentage of Kentucky bluegrass in a turf sward when seeded at different seasons, Verona, WI.

\begin{tabular}{|c|c|c|c|}
\hline \multirow[b]{2}{*}{ Seed mixture ${ }^{y}$} & \multicolumn{3}{|c|}{ Time of seeding ${ }^{z}$} \\
\hline & Late summer & Dormant & Spring \\
\hline & & 18 Aug. 2005 & \\
\hline $95: 5$ & 69.8 & 79.2 & 62.2 \\
\hline $80: 20$ & 62.5 & 73.8 & 42.8 \\
\hline $70: 30$ & 61.5 & 72.8 & 39.8 \\
\hline $0: 100$ & 0.2 & 0.2 & 0.2 \\
\hline \multicolumn{2}{|c|}{$\mathrm{LSD}_{0.05}$ between mixes within a planting time } & 11.6 & \\
\hline \multirow{2}{*}{\multicolumn{2}{|c|}{$\mathrm{LSD}_{0.05}$ between planting times within a mixture }} & 11.4 & \\
\hline & & 20 Oct. 2005 & \\
\hline $95: 5$ & 71.6 & 78.8 & 52.8 \\
\hline $80: 20$ & 61.2 & 66.2 & 40.8 \\
\hline $70: 30$ & 62.8 & 65.8 & 33.6 \\
\hline $0: 100$ & 0.2 & 0.2 & 0.0 \\
\hline \multicolumn{2}{|c|}{$\mathrm{LSD}_{0.05}$ between mixes within a planting time } & 10.8 & \\
\hline \multicolumn{2}{|c|}{$\mathrm{LSD}_{0.05}$ between planting times within a mixture } & 13.4 & \\
\hline
\end{tabular}

${ }^{2}$ Late summer was 30 Aug. 2004, dormant seeding was 26 Nov. 2004, and spring was 28 Apr. 2005.

${ }^{\mathrm{y}}$ Mixtures were ratios (by weight) of Kentucky bluegrass (Poa pratensis):perennial ryegrass (Lolium perenne).

LSD $=$ least significant difference.

\section{Literature Cited}

Brede, A.D. and J.H. Duich. 1984a. Initial mowing of Kentucky bluegrass-perennial ryegrass seedling turf mixtures. Agron. J. 76:711-714.
Brede, A.D. and J.H. Duich. 1984b. Establishment characteristics of Kentucky bluegrassperennial ryegrass turf mixtures as affected by seeding rate and ratio. Agron. J. 76:875879.
Cockerham, S.T. and D.J. Brinkman. 1989. A simulator for cleated-shoe sports traffic on turfgrass research plots. Calif. Turfgrass Cult. 39:9-12.

Dunn, J.H., E.H. Ervin, and B.S. Fresenburg. 2002. Turf performance of mixtures and blends of tall fescue, Kentucky bluegrass, and perennial ryegrass. HortScience 37:214-217.

Hsiang, T., K. Carey, B. He, and J.E. Eggens. 1997. Composition of mixtures of four turfgrass species four years after seeding under non-wear conditions. Intl. Turfgrass Soc. Res. J. 8:671679.

Larsen, S.O., C. Andreason, and P. Kristofferson. 2004. Differential sowing time of turfgrass species affects the establishment of mixtures. Crop Sci. 44:1315-1322.

Larsen, S.U. and B.M. Bibby. 2005. Differences in thermal time requirement for germination of three turfgrass species. Crop Sci. 45:2030-2037.

Marshall, G. 1987. A review of the biology and control of selected weed species in the genus Oxalis: O. stricta L., O. latifolia H.B.K. and O. pes-caprae L. Crop Prot. 6:355-364.

Minner, D.D. and F.J. Valverde. 2005. Performance of cool-season grass species under simulated traffic. Intl. Turfgrass Res. Soc. J. 10:393-397.

NTEP (National Turfgrass Evaluation Program). 2003. 1999 National perennial ryegrass testFinal report. 24 May 2007. <www.ntep.org>.

Shearman, R.C. and J.B. Beard. 1975a. Turfgrass wear tolerance mechanisms: I. Wear tolerance of seven turfgrass species and quantitative methods for determining turfgrass wear injury. Agron. J. 67:208-211.

Shearman, R.C. and J.B. Beard. 1975b. Turfgrass wear tolerance mechanisms: II. Effects of cell wall constituents on turfgrass wear tolerance. Agron. J. 67:211-215.

Statistix. 2003. Statistix 8 user's manual. Analytical Software, Tallahassee, FL.

Stier, J.C. 2000. Lawn establishment and renovation. Univ. Wisc. Ext. Bull. A3434.

Stier, J.C., J. Bae, and G. Jung. 2005. Composition of Kentucky bluegrass and perennial ryegrass mixtures subjected to traffic. Intl. Turfgrass Res. Soc. J. 10:645-653. 